\title{
Management of airway compromise in a paediatric mediastinal mass
}

\author{
Miane Min Yan Ng (1) , Andrew Hall, ${ }^{2}$ Peter Sidgwick, ${ }^{3}$ Richard Hewitt ${ }^{4}$
}

${ }^{1}$ Otolaryngology, Great Ormond Street Hospital for Children NHS Trust, London, UK

${ }^{2}$ Otolaryngology, Great Ormond Street Hospital for Children, London, UK

${ }^{3}$ Paediatric Intensive Care Unit, Great Ormond Street Hospital for Children, London, UK ${ }^{4}$ ENT Head and Neck Surgery, Great Ormond Street Hospital for Children NHS Trust, London, UK

Correspondence to Dr Miane Min Yan Ng; miane.ng@gmail.com

Accepted 5 December 2020

Check for updates

(c) BMJ Publishing Group Limited 2021. No commercial re-use. See rights and permissions. Published by BMJ.

\begin{tabular}{l}
\hline To cite: Ng MMY, Hall A, \\
Sidgwick P, et al. BMJ Case \\
Rep 2021;14:e236446. \\
doi:10.1136/bcr-2020- \\
236446 \\
\hline
\end{tabular}

\section{DESCRIPTION}

A previously fit and well 3-month-old baby was admitted to his local hospital with worsening stridor following a 2-week history of crouplike symptoms. Chest radiograph shows a large area of mediastinal and bilateral upper-zone opacification (figure 1). Due to concerns of progressive airway compression and potential difficulties, securing a definitive airway referral was made to a tertiary centre with an extracorporeal membrane oxygenation (ECMO) service for further management and investigation. The patient was stabilised with steroids and adrenaline nebulisers and given positive-pressure ventilation for transfer.

With the full ECMO team in attendance, a 3.5 endotracheal tube was placed under direct vision in theatre by Ears, Nose and Throat (ENT) surgeons following rigid bronchoscopy evaluation of the airway. Subsequent imaging with CT thorax illustrates a $9 \times 6.5 \times 6 \mathrm{~cm}$ predominantly homogeneous, soft-tissue mass in the anterior mediastinum with moderate airway compression (figure 2). Biopsy results later confirmed diagnosis of thymoma.

Thymoma is an aggressive lympho-epithelial neoplasm of the anterior mediastinum. While they are the most common anterior mediastinal tumours in adults, they represent less than $1 \%$ of all mediastinal tumours in children. ${ }^{1}$ Contrast-enhanced CT is the current gold-standard investigation for evaluating and staging a thymoma. Due to the rarity of such cases, there is currently no universal staging system; the Masaoka staging system is widely recognised and used. ${ }^{2}$ Treatment depends on

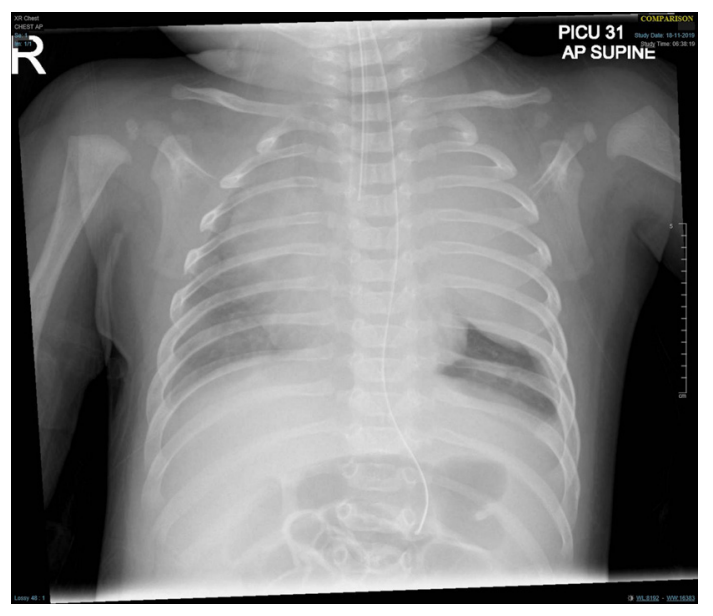

Figure 1 Plain film chest radiograph shows a large mediastinal mass and bilateral upper-zone opacification.

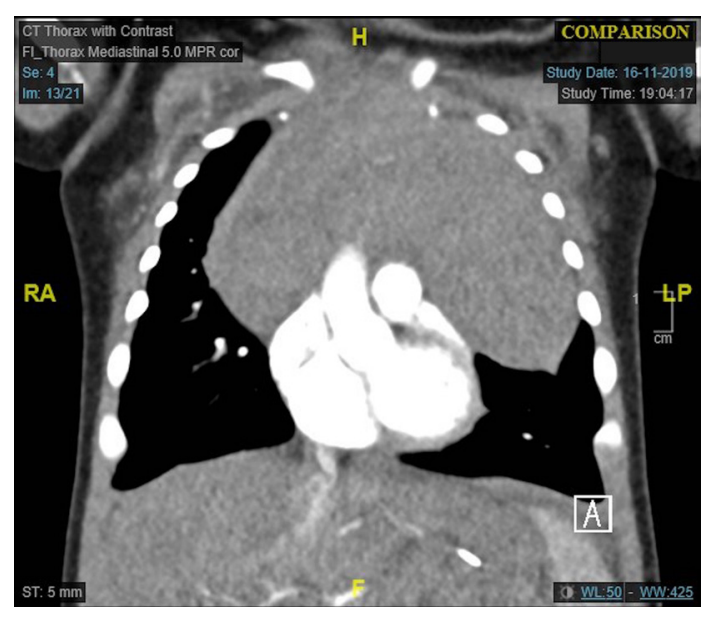

Figure 2 Coronal CT thorax shows a large mass of the anterior mediastinum encasing the great vessels.

staging and is discussed through a multidisciplinary team approach. This case was treated with highdose steroids, but there was subsequent expansion of the thymoma on steroid weaning, and the patient ultimately required thymectomy.

In this case of a paediatric mediastinal mass with worsening acute airway symptoms, the impending potential for a 'can't intubate, can't ventilate' situation was recognised by all teams involved. There were also concerns that rigid bronchoscopy or tracheostomy by ENT may not be possible owing to airway compression and lesion size. This necessitated expediated transfer to a tertiary centre where a multidisciplinary airway management strategy involving specialist paediatric ENT, anaesthetics and ECMO team afforded the best opportunity to safely secure the airway.

\section{Learning points}

- Thymoma is a rare cause of a mediastinal mass in children.

- A large mediastinal mass such as a thymoma can cause airway compression and or obstruction.

- Identification of potential airway difficulties and prompt consideration of centres could support extracorporeal membrane oxygenation as rescue airway intervention.

Contributors All authors, MMYN, AH, PS and RH, contributed to writing and revision of this manuscript. Case identified by AH. Project led by $\mathrm{AH}$ and $\mathrm{RH}$. 


\section{Images in...}

Funding The authors have not declared a specific grant for this research from any funding agency in the public, commercial or not-for-profit sectors.

Competing interests None declared.

Patient consent for publication Parental/guardian consent obtained.

Provenance and peer review Not commissioned; externally peer reviewed.

\section{ORCID iD}

Miane Min Yan Ng http://orcid.org/0000-0001-5127-1116

\section{REFERENCES}

1 Saha S, Suhani S, Basak A, et al. Pediatric thymoma with a difference: report of a case and review of literature. J Surg Tech Case Rep 2014;6:64-6.

2 Detterbeck FC, Stratton K, Giroux D, et al. The IASLC/ITMIG thymic epithelial tumors staging project: proposal for an evidence-based stage classification system for the forthcoming (8th) edition of the TNM classification of malignant tumors. J Thorac Oncol 2014;9:565-72.

Copyright 2021 BMJ Publishing Group. All rights reserved. For permission to reuse any of this content visit

https://www.bmj.com/company/products-services/rights-and-licensing/permissions/

BMJ Case Report Fellows may re-use this article for personal use and teaching without any further permission.

Become a Fellow of BMJ Case Reports today and you can:

- Submit as many cases as you like

Enjoy fast sympathetic peer review and rapid publication of accepted articles

- Access all the published articles

Re-use any of the published material for personal use and teaching without further permission

Customer Service

If you have any further queries about your subscription, please contact our customer services team on +44 (0) 2071111105 or via email at support@bmj.com.

Visit casereports.bmj.com for more articles like this and to become a Fellow 